Pak. J. Agri. Sci., Vol. 55(1), 23-27; 2018

ISSN (Print) 0552-9034, ISSN (Online) 2076-0906

DOI:10.21162/PAKJAS/18.4071

http://www.pakjas.com.pk

\title{
DEVELOPMENT OF EFFICIENT MICROPROPAGATION SYSTEM FOR E. camaldulensis WITH RESPECT TO AGE OF EXPLANTS
}

\author{
Ammara Ahad, Edwin John, Asma Maqbool* and Kauser Abdulla Malik \\ Department of Biological Sciences Forman Christian College, Lahore 54600, Pakistan \\ "Corresponding author's e-mail: asmamaqbool@fccollege.edu.pk
}

\begin{abstract}
Efficient regeneration protocol is important for mass propagation, genetic transformation and germplasm alteration of desired plants. Thus, development of an efficient protocol is of the considerable importance for further genetic manipulation. In vitro plant regeneration was studied from two age groups of seedlings (2-11 weeks and 12-21 weeks old) by using their cotyledons, hypocotyls \& leaf segments as explants. Shoot organogenesis was evaluated by using different explants on MS medium supplemented with varying concentrations of phtyohormones $(1 \mathrm{mg} / \mathrm{l} \mathrm{BAP} ; 0.2 \mathrm{mg} / \mathrm{l} \mathrm{BAP}+1 \mathrm{mg} / \mathrm{l} \mathrm{Zn} ; 0.5 \mathrm{mg} / \mathrm{l} \mathrm{BAP}+0.1 \mathrm{mg} / \mathrm{l}$ NAA; $1.5 \mathrm{mg} / 1 \mathrm{BAP}+0.5 \mathrm{mg} / \mathrm{l} \mathrm{NAA})$. Similarly, rooting of regenerated shoots was optimized on different concentrations of IBA $(0.1 \mathrm{mg} / 1 ; 0.5 \mathrm{mg} / \mathrm{l} ; 1 \mathrm{mg} / \mathrm{l})$. Hypocotyls of two to eleven weeks old seedlings as explants showed the best results of direct organogenesis on BAP $(0.5 \mathrm{mg} / \mathrm{l})$ and NAA $(0.1 \mathrm{mg} / \mathrm{l})$ in 21 days. However, BAP $(0.2 \mathrm{mg} / \mathrm{l})$ and $\mathrm{Zn}(1 \mathrm{mg} / \mathrm{l})$ showed no growth. Indole-3-butyric acid ( $1 \mathrm{mg} / \mathrm{l})$ induced rooting within a minimum period of 12 days. Overall, rate of shoot and root formation was found to be $50 \%$, respectively. Successfully, the platelets were acclimatized in net house and further transferred to open field conditions.
\end{abstract}

Keywords: Direct organogenesis, indole-3-butyeric acid, micropropagation, in vitro regeneration

\section{INTRODUCTION}

Among the world important hardwood plantation, eucalypts occupied significant position due to their paper pulp, fuel wood and timber. E. camaldulensis being widely distributed and drought tolerant species has the ability to adopt changing rainfall as well as temperature conditions. This property has made it useful in economical and industrial prospects (Butcher et al., 2009; Pinto et al., 2013). Medicinal Eucalyptus oil is largely employed in the preparation of liniments, inhalants, cough syrups, ointments, toothpaste, and pharmaceutical flavouring. The oil obtained from eucalyptus leaves have found various applications in daily life due to their antiseptic, anti-inflammatory and antipyretic properties (Silva et al., 2003; Akin et al., 2007; Cheng et al., 2009).

Micropropagation of E. camaldulensis has been documented previously in vitro via direct organogenesis (Yashoda et al., 1997; Kawaoka et al., 2006; Pinto et al., 2013) and indirect organogenesis (Mullins et al., 1997; Ho et al., 1998; Harcourt et al., 2000; Rahim et al., 2003; Dibax et al., 2005; Dibax et al., 2010; Ahad et al., 2014) and indirect somatic embryogenesis (Prakash and Gurumurthi, 2010). Deepika et al. (2011) established in vitro shoot regeneration on MS basal medium supplemented by plant growth hormones (BAP, NAA and TDZ) for various eucalyptus genotypes i.e. $E$. grandis, E. grandis $\times E$. nitens, $E$. grandis $\times E$. camaldulensis and E. grandis $\times$ E. urophylla. A study on genetic modification of eucalyptus in order to modify the cellulose and hemicellulose biosynthesis to increase the biomass in a short period of time has been reported (Dibax et al., 2010).

In comparison to other woody plants this species is very recalcitrant; the problem with eucalyptus is its lower transformation as well as regeneration ability due to heavy leaching of phenolic compounds (Tournier et al., 2003). During Agrobacterium mediated genetic transformation, the transformed tissues usually lose their potential to regenerate and develop plants. Particularly, the failure of well develop rooting systems to initiate roots from transformed shoots show the major obstacle in obtaining whole regenerated transgenic plants. The current study was an attempt to develop a simple, reliable and efficient in vitro regeneration protocol for $E$. camaldulensis. The explants used were cotyledons, hypocotyls and leaf segments. Effect of age of explants on regeneration potency was also monitored.

\section{MATERIALS AND METHODS}

Plant material and sterilization: Seeds were collected from Ayub Agricultural Research Institute, Faisalabad, Pakistan. First, they were surface sterilized by submerging in $70 \%$ ethanol for 60 second followed by washing with sterile distilled water then immersed in sodium hypochlorite (100\%) for 20 minutes. An additional washing with $70 \%$ ethanol for 1 minute was also given. Later on, the seeds were rinsed 3-4 times with autoclaved distilled water (Ahad et al., 2014).

Germination of seeds was obtained on half strength MS basal medium (Murashige and Skoog, 1962) having 3\% sucrose and 
4\% Gelzan (PhytoTechnology Laboratories®). In the current study, seedlings of two age groups (2-11 week and 12-21 week) were used. The first age group was termed as young seedlings and second as old seedlings. For both age groups cotyledons, hypocotyls \& leaf segment $(0.5-0.8 \mathrm{~cm})$ were used as explants.

Regeneration medium: For optimization of regeneration four shoot induction media (SIM1-SIM4) were used (Table 1). Light intensity of $20 \mu \mathrm{mol} \mathrm{m} \mathrm{m}^{-2} \mathrm{~s}^{-1}$ was provided by white fluorescent tube lights and the culture room temperature was maintained at $25^{\circ} \mathrm{C}$.

Table 1. Combination of different plant regulators used for regeneration in $\boldsymbol{E}$. camaldulensis.

\begin{tabular}{ll}
\hline Name of the media & $\begin{array}{l}\text { Composition of media in MS } \\
\text { medium }\end{array}$ \\
\hline SIM1 & $1.0 \mathrm{mg} / 1 \mathrm{BAP}$ \\
SIM2 & $0.2 \mathrm{mg} / 1 \mathrm{BAP}+1 \mathrm{mg} / 1 \mathrm{Zn}$ \\
SIM3 & $0.5 \mathrm{mg} / 1 \mathrm{BAP}+0.1 \mathrm{mg} / 1 \mathrm{NAA}$ \\
SIM4 & $0.5 \mathrm{mg} / 1 \mathrm{BAP}+0.5 \mathrm{mg} / 1 \mathrm{NAA}$ \\
\hline
\end{tabular}

Rooting medium: Elongated shoots were further transferred for rooting in MS medium fortified with IBA (Table 2). Shoots on root induction medium (RIM 1-3) were kept in light at $25^{\circ} \mathrm{C}$ in tissue culture room for 2 weeks. All media contained $3 \%$ sucrose with $\mathrm{pH}$ adjusted at 5.8.

Table 2. Rooting media for $E$. camaldulensis.

\begin{tabular}{lc}
\hline Name of media & $\begin{array}{c}\text { Composition of media in MS } \\
\text { medium }\end{array}$ \\
\hline RIM1 & $0.1 \mathrm{mg} / 1 \mathrm{IBA}$ \\
RIM2 & $0.5 \mathrm{mg} / 1 \mathrm{IBA}$ \\
RIM3 & $1.0 \mathrm{mg} / 1 \mathrm{IBA}$ \\
\hline
\end{tabular}

Acclimatization: Rooted plantlets with height $6-8 \mathrm{~cm}$ were acclimatized in vitro by placing in pots $(3 \times 3$ inch) with a mixture of peat moss, perlite and vermiculite in a ratio of $2: 1: 1$, respectively. Plants were acclimatized under high humidity condition. The humidity was maintained in pots by covering them with polypropylene bags which was gradually decreased by cutting edges of the polypropylene bags until no moisture remained in the bag. Acclimatization was done in green house at $25^{\circ} \mathrm{C}$. Hoagland solution (1X, $20 \mathrm{ml}$ ) was also given to plants after every 7 day. Acclimatized plants were subjected to hardening in silt and loam soil under net house conditions during spring season.

\section{RESULTS}

Response of explants was different on different combination of phytohormones. Direct shoot organogenesis was induced by SIM1 and SIM3 (Fig. 1 a,b,c,d) within 21 days. SIM3 proved to be the best growth hormone combination as it induced more number of bud formation per explant (Table 3 ).
Further, the age of seedlings was monitored to check its effect on regeneration phenomenon. Young as well as old seedlings responded in the same manner on these (SIMI \& SIM3) hormonal combinations. Regeneration efficiency of SIM3 was up to $50 \%$ (Table 4 ).

Table 3. Comparison of shoot induction media.

\begin{tabular}{lcccc}
\hline $\begin{array}{l}\text { Basal culture } \\
\text { medium }\end{array}$ & $\begin{array}{c}\text { PGR } \\
\text { combination }\end{array}$ & $\begin{array}{c}\text { Explants } \\
\text { inoculated }\end{array}$ & $\begin{array}{c}\text { Explants } \\
\text { regenerated }\end{array}$ & Days \\
\hline MS & SIM1 & 12 & 2 & 30 \\
& SIM2 & 12 & 0 & 30 \\
& SIM3 & 12 & 09 & 30 \\
& SIM4 & 12 & 01 & 30 \\
\hline
\end{tabular}

Table 4. Regeneration efficiency of SIM3.

\begin{tabular}{|c|c|c|c|}
\hline $\begin{array}{l}\text { No. of } \\
\text { experiments }\end{array}$ & $\begin{array}{c}\text { Inoculated } \\
\text { explants }\end{array}$ & $\begin{array}{c}\text { Regenerated } \\
\text { shoots }\end{array}$ & $\begin{array}{c}\% \\
\text { Regeneration }\end{array}$ \\
\hline Experiment 1 & 638 & 322 & 50.4 \\
\hline Experiment 2 & 326 & 160 & 49.07 \\
\hline Data generated & Total explants & $\begin{array}{l}\text { Regenerated } \\
\text { plantlets }\end{array}$ & Regeneration \\
\hline Frequency & 964 & 482 & 50 \\
\hline
\end{tabular}

However, Indirect organogenesis was observed on SIM4 when young seedlings were used as explants, swelling was observed in 19 days while callus induction after 28 days, brown embryonic calli were formed after 36 days of incubation and shoot formation after 45 days of incubation (Fig. 1e \& f).

Old seedlings on SIM4, responded in a different manner. Enlargement as well as swelling was seen after 30 days and callus formation initiated in 40 days followed by shoot formation after 60 days of incubation. No callus formation was observed within one month. Whereas, the direct shoot organogenesis was also seen in the some cotyledons and hypocotyls (Fig. 1g). No regeneration was observed on SIM2 even after two months (Table 3). It was concluded that frequency of regeneration decreased with ageing of explants. The results indicated that leaf as explants showed poor regeneration response as compare to hypocotyls irrespective of the age of seedling. Adventitious buds originated as clumps on whole hypocotyls especially at nodal area while in leaf it emerged from petiole region. Most of the leaf portion got necrotic due to heavy release of phenolics when explants were excised to small portions for experimental purposes.

Regenerated shoots $(2.5-3 \mathrm{~cm})$ obtained from SIM3 were shifted to rooting media. At concentration of 1 and $0.1 \mathrm{mg} / 1$ IBA within 12 days, root induction was observed (Fig. 1h). Delayed root formation (after 27 days) was seen on MS medium supplemented with $0.5 \mathrm{mg} / 1$ IBA (Table 5). On each plantlet an average of 4-6 roots were formed. Root growth was normal but after four weeks of culture, browning was observed. Root regeneration was observed from 25 to $50 \%$ in inoculated shoots. In micropropagation, hardening of tissue culture derived plantlets is a critical step. But in present study, 

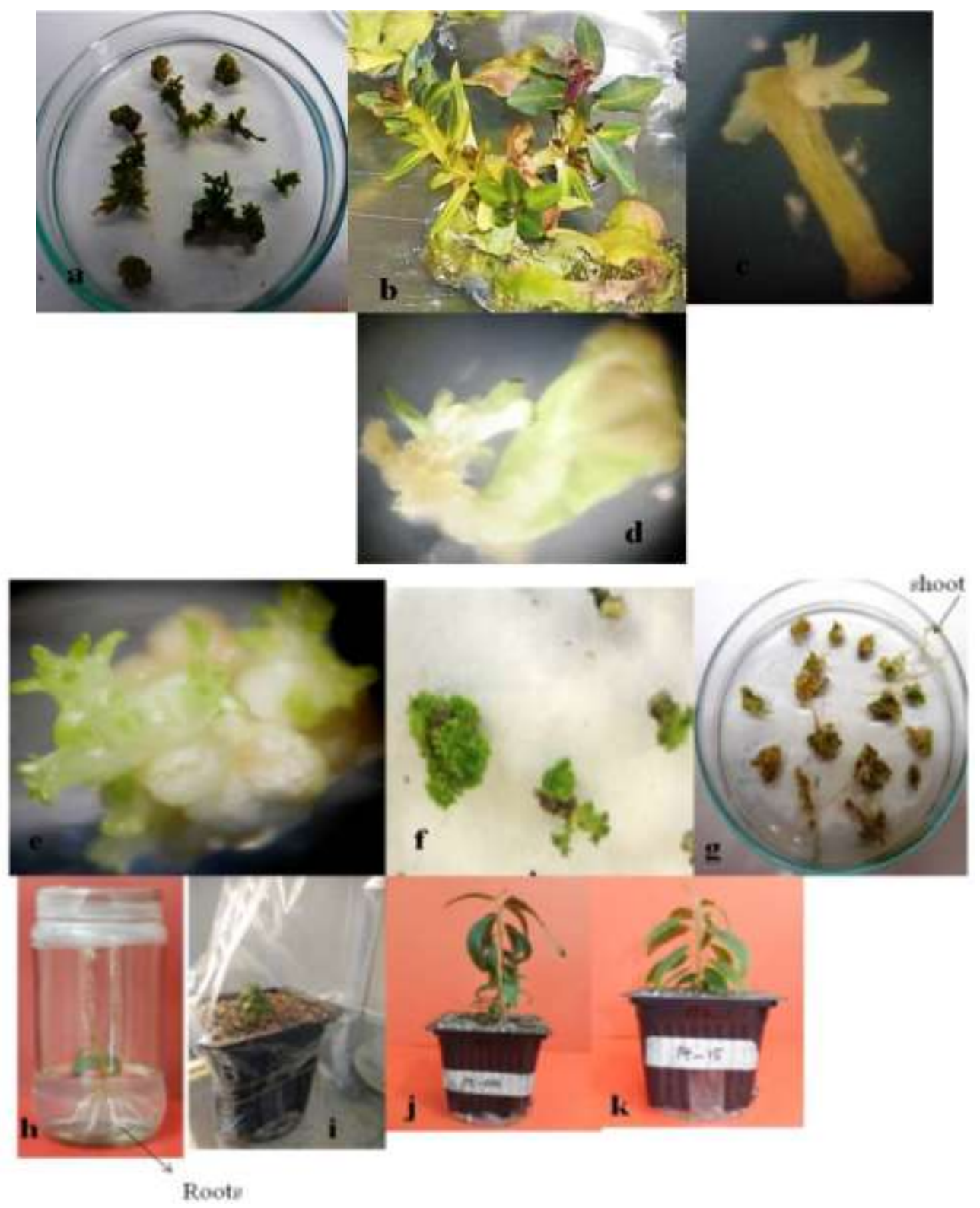

Figure1. Photographic presentation of in vitro shoot and root induction in E. camaldulensis: a,b. Organogenesis on SIM3 $(0.5 \mathrm{mg} / \mathrm{l}$ BAP+ 0.1mg/l NAA) by direct regeneration; c,d. regeneration on SIM1; e,f. shoot regeneration on SIM4 $(1.5 \mathrm{mg} / \mathrm{l}$ BAP+0.5mg/l NAA) via indirect organogenesis; g. Shoot and root formation in old seedlings; h. Root induction on RIM3 (1mg/l IBA); i,j,k. acclimatized $E$. camaldulensis plants.

transfer of plantlets in pots having silty and loamy soil in net house gave $100 \%$ survival rate and thus plants were successfully acclimatized (Fig. $1 \mathrm{i}, \mathrm{j}, \mathrm{k})$.

Table 5. Root formation of E. camaldulensis.

\begin{tabular}{ccccc}
\hline $\begin{array}{c}\text { PGR (IBA } \\
\text { mg/l) }\end{array}$ & $\begin{array}{c}\text { Shoot } \\
\text { inoculated }\end{array}$ & $\begin{array}{c}\text { Shoots } \\
\text { formed roots }\end{array}$ & $\begin{array}{c}\text { Culture } \\
\text { time }\end{array}$ & $\begin{array}{c}\text { Media } \\
\text { efficiency }\end{array}$ \\
\hline 0.1 & 4 & 1 & 12 & $25 \%$ \\
0.5 & 4 & 1 & 27 & $25 \%$ \\
1 & 6 & 3 & 12 & $50 \%$ \\
\hline
\end{tabular}

\section{DISCUSSION}

Eucalyptus species are the mostly propagated as a raw material for production of cellulose. Developing a regeneration protocol for this species would be an important step towards the improvement of its properties for the utilization in pulp and paper industries. Several reports regarding transformation and micropropagation methods in various eucalyptus genotypes are available (Kawaoka et al., 2006; Deepika et al., 2011; Ahad et al., 2014). 
Sterilization is an important step in order to get in vitro seedlings as explant material. During present work, in process of sterilization, the most common contamination was fungal spores and its hypae. Use of $\mathrm{NaClO}$ proved effective in controlling contamination. These results were supported by (Dibax et al., 2010) and (Nugent et al., 2001) who reported different concentrations of $\mathrm{NaClO}$ helpful for sterilization of eucalyptus. According to Tournier et al. (2003) in comparison to other woody plants, the problem with eucalyptus species is their lower transformation and regeneration rate due to leaching of phenolic compounds. Thus, evaluation of efficient shoot inducing medium, best target material for the differentiation and age of explant with respect to transformation is of vital importance. On SIM3 and SIM4 (Table 1) young seedlings were proved the best target tissue for regeneration; it showed survival up to $60-70 \%$. This regeneration response decreased to $10-20 \%$ in case of old seedlings. González et al. (2002) recommended 2 and 15 days old cotyledons and hypocotyls after germination for eucalyptus genetic transformation and concluded that actively dividing cells and tissues were more efficient as compared to older explants. Work done on E. gunnii leaves showed that regeneration was initiated from meristems located in the leaf base and connected to the vascular bundles (Herve et al., 2001) However, Bandyopadhyay and Hamill (2000) documented more regeneration capabilities in hypocotyl derived calli in E. nitens and E. globules.

The current study has same findings in regenerative response of cotyledons and hypocotyls. A combination of auxins (NAA) and cytokinins (BAP) in lower concentration favored direct organogenesis from hypocotyls and cotyledons of Eucalyptus tereticornis (Girijashankar, 2011; Prakash and Gurumurthi, 2009). From early times, Indole butyric acid (IBA) is widely used auxin to stimulate the rooting phenomenon in plant cuttings (Blazich, 1988; Hartmann and Kester, 1975; Wiesman et al., 1988). In present research $1 \mathrm{mg} / \mathrm{l}$ IBA showed root formation in 12 days (Table 5). Current results are in consistent with published literature. The documented data also showed, $1 \mathrm{mg} / \mathrm{l} \mathrm{IBA}$ as successful in inducing roots in various genotypes of eucalyptus (Ho et al., 1998; Prakash and Gurumurthi, 2009). However, another report by Kawaoka et al. (2006), showed $0.5 \mathrm{mg} / \mathrm{l}$ IBA effective in root formation in the case E. camaldulensis.

Conclusion: The protocol established in this study provides a simple and efficient system for introduction of desirable characters in Eucalyptus camaldulensis. This shows potential for in vitro mass propagation and the development of germplasm under different climatic conditions. It also suggests that in vitro young seedlings (2-12 week age) are good target tissues for producing transgenic plants via micropropagation.

\section{REFERENCES}

Ahad, A., A. Maqbool and K.A. Malik. 2014. Optimization of Agrobacterium tumefaciens mediated transformation in Eucalyptus camaldulensis. Pak. J. Bot. 46:735-740.

Akin-Osanaiye, B., A. Agbaji and M. Dakare. 2007. Antimicrobial Activity of Oils and Extracts of Cymbopogon citratus (Lemon Grass), Eucalyptus citriodora and Eucalyptus camaldulensis. J. Med. Sci. 7:694-697.

Bandyopadhyay, S. and J.D. Hamill . 2000. Ultrastructural studies of somatic embryos of Eucalyptus nitens and comparisons with zygotic embryos found in mature seeds. Ann. Bot. 86:237-244.

Blazich., F.A. 1988. Mineral nutrition and adventitious rooting. Adv. Plant Sci. 2: 61-69.

Butcher, P., M. McDonald and J. Bell. 2009. Congruence between environmental parameters, morphology and genetic structure in Australia's most widely distributed eucalypt, Eucalyptus camaldulensis. Tree Genet. Genomes 5:189-210.

Cheng, S.S., C.G. Huang, Y.J. Chen, J.J. Yu, W.J. Chen and S.T. Chang. 2009. Chemical compositions and larvicidal activities of leaf essential oils from two eucalyptus species. Bioresour. Technol. 100:452-456.

Deepika, R., A. Veale, C. Ma, S.H. Strauss and A.A. Myburg. 2011. Optimization of a plant regeneration and genetic transformation protocol for Eucalyptus clonal genotypes. BMC Proc. 57:132-134.

Dibax, R., Cd.L. Eisfeld, F.L. Cuquel, H. Koehler and M. Quoirin. 2005. Plant regeneration from cotyledonary explants of Eucalyptus camaldulensis. Sci. Agric. 62:406-412.

Dibax, R., R.C. Quisen, C. Bona and M. Quoirin. 2010. Plant regeneration from cotyledonary explants of Eucalyptus camaldulensis Dehn and histological study of organogenesis in vitro. Braz. Arc. Biol. Technol. 53:311318.

Girijashankar, V. 2011. Genetic transformation of Eucalyptus. Physiol. Mol. Biol. Plants 17:9-23.

González, E.R., A. de Andrade, A.L. Bertolo, G.C. Lacerda, R.T. Carneiro, V.A.P. Defávari, M.T.V. Labate and C.A. Labate. 2002. Production of transgenic Eucalyptus grandis $\times E$. urophylla using the sonication-assisted Agrobacterium transformation (SAAT) system. Funct. Plant Biol. 29:97-102.

Harcourt, R., J. Kyozuka, R. Floyd, K. Bateman, H. Tanaka, V. Decroocq, D. Llewellyn, X. Zhu, W. Peacock and E. Dennis. 2000. Insect and herbicide resistant transgenic eucalypts. Mol. Breed. 6:307-315.

Hartmann, H.T. and D.E. Kester. 1975. Plant Propagation: Principles and practices; $3^{\text {nd }}$ Ed. Prentice-Hall, Englewood Cliffs, N.J. 
Herve, P., A. Jauneau, M. Paques, J.N. Marien, A.M. Boudet and C. Teulieres. 2001. A procedure for shoot organogenesis in vitro from leaves and nodes of an elite Eucalyptus gunnii clone: comparative histology. Plant Sci. 161:645-653.

Ho, C.K., S-H. Chang, J.Y. Tsay, C.J. Tsai, V. Chiang and ZZ. Chen. 1998. Agrobacterium tumefaciens-mediated transformation of Eucalyptus camaldulensis and production of transgenic plants. Plant Cell Rep. 17:675680.

Kawaoka, A., K. Nanto, K. Ishii and H . Ebinum. 2006. Reduction of lignin content by suppression of expression of the LIM domain transcription factor in Eucalyptus camaldulensis. Silvae Genet. 55:269-277.

Mullins, K., D. Llewellyn, V. Hartney, S. Strauss and E. Dennis. 1997. Regeneration and transformation of Eucalyptus camaldulensis. Plant Cell Rep. 16:787-791.

Nugent, G., S.F. Chandler, P. Whiteman and T.W. Stevenson. 2001. Adventitious bud induction in Eucalyptus globulus Labill. In Vitro Cell Dev. Biol. Plant 37:388-391.

Pinto, G., C. Araújo, C. Santos and L. Neves. 2013. Plant regeneration by somatic embryogenesis in Eucalyptus spp.: current status and future perspectives. South. Forests 75:59-69.

Prakash, M. and K. Gurumurthi. 2009. Genetic transformation and regeneration of transgenic plants from precultured cotyledon and hypocotyl explants of Eucalyptus tereticornis Sm. using Agrobacterium tumefaciens. In Vitro Cell Dev. Biol. Plant 45:429-434.
Prakash, M. and K. Gurumurthi. 2010. Effects of type of explant and age, plant growth regulators and medium strength on somatic embryogenesis and plant regeneration in Eucalyptus camaldulensis. Plant Cell Tiss. Org. Cult. 100:13-20.

Rahim, F., M. Jabeen and I. Ilahi. 2003. Mass propagation in Eucalyptus camaldulensis Dehn. Asian J. Plant Sci. 2:184-187

Silva, J., W. Abebe, S. Sousa, V. Duarte, M. Machado, F. Matos. 2003. Analgesic and anti-inflammatory effects of essential oils of Eucalyptus. J. Ethnopharmacol. 89:277283.

Tournier, V., S. Grat, C. Marque, C.W. El Kayal, R. Penchel, G.de Andrade, A.-M. Boudet and C. Teulieres. 2003. An efficient procedure to stably introduce genes into an economically important pulp tree (Eucalyptus grandis $\times$ Eucalyptus urophylla). Transgenic Res. 12:403-411.

Wiesman, Z., J. Riov and E. Epstein. 1988. Comparison of movement and metabolism of indole-3-acetic acid and indole-3-butyric acid in mung bean cuttings. Physiol. Plant. 74:556-560.

Yasodha, R., R. Sumathi and K. Gurumuthi. 1997. Micropropagation of difficult to propagate clones of eucalypts. In: Silvilculture and Improvement of Eucalypts. Biotechnology applied to genetic improvement of tree species. Proc. IUFRO Conference, Salvador, Brazil 2:123-126. 